\title{
The Osler Library of the History of Medicine: McGill's Medical Memory
}

\author{
Christopher Lyons and David S. Crawford*
}

Sir William Osler bequeathed his library to McGill University in 1919; a decade later, the $\mathbf{8 0 0 0}$ volumes arrived in Montreal. Then, as now, the collection consisted of primary works ("rare books"), secondary commentaries, and current works on the history of the health sciences. In the last $\mathbf{8 0}$ years the collection has grown considerably and the library now adds about 1,000 books to its collection yearly (mainly current publications) and receives 200 current serial titles. The Osler Library is one of the largest "history of medicine" libraries in the world and the largest of its kind in Canada. The library tries to collect current material on the history of the health sciences from all over the world and attempts to collect all medical history published in Canada. The Osler offers its resources to researchers and students through its website, publications and Research Travel Grant programme.

The librarian of today, and it will be true still more of the librarians of tomorrow, are not fiery dragons interposed between the people and the books. They are useful public servants, who manage libraries in the interest of the public... Many think still that a great reader, or a writer of books, will make an excellent librarian. This is pure fallacy.

- William Osler, (1)

\footnotetext{
*To whom correspondence should be addressed: Christopher Lyons Liaison Librarian

Osler Library of the History of Medicine

McGill University

christopher.lyons@mcgill.ca

514-398-4475, ext. 09847

David S. Crawford

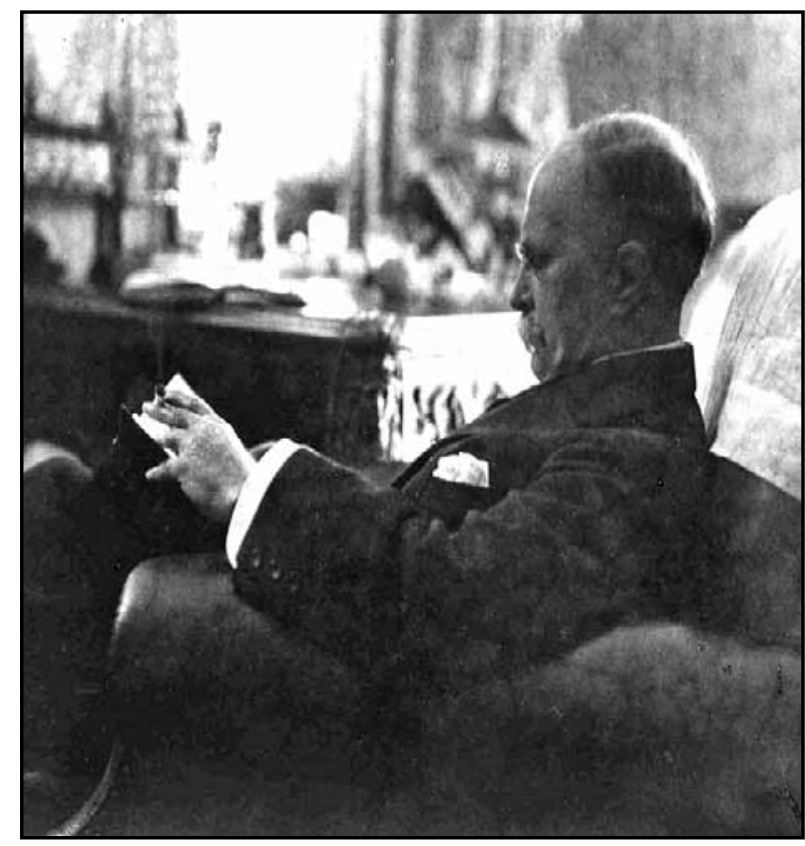

Figure 1: Sir William Osler, 1849-1919 
William Osler was born in Bond Head, Canada West (now Ontario) in 1849. After commencing his education in Toronto, he became a student at McGill University in Montreal and graduated in medicine in 1872. Osler's life and career have been well described in two major biographies $(2,3)$. His career took him from being a professor at McGill $(1874-1884)$ to the University of Pennsylvania (1884 -1889), Johns Hopkins University (1889-1905), and finally to Oxford as Regius Professor of Medicine (1905-1919) (see Figure 1).

When he died in 1919, Osler was probably the most famous doctor in the western world: apart from many articles, letters and lecture presentations, he authored and edited the textbook, Principles and Practice of Medicine. The textbook, first published in 1892, was a best seller. It went through more than eight editions and was translated into French, German, Spanish, Portuguese, Chinese and Russian (4). "Oslerian medicine" became such a great interest that "Osler Clubs" were established throughout the world. Some, such as those in the United States, London, Japan and at McGill, continue today, though now they more often discuss "history" and "Osler" rather than current medical practice.

Osler was an early proponent of the need to listen to the patient: he realised that disease and health are closely connected to living conditions. He was strongly influenced by Sir Thomas Browne, whose seventeenth century work Religio Medici, guided him throughout his career. By the time he died, Osler had been awarded a baronetcy (in 1911) and held numerous honorary degrees. Though Osler was a very serious scholar, he was also very human and enjoyed teasing and practical jokes. In his letters, speeches, and articles he comes across clearly as a person whom it would have been a pleasure to meet. Osler created a mischievous "alter ego", Egerton Yorrick Davis, under whose name a variety of letters and articles appeared on subjects ranging from the fanciful customs of the "Indian Tribes about Great Slave Lake" to vaginismus and Peyronie's Disease. Such was the notoriety of "EYD" that some medical writers continue to use this pseudonym today (5).

Osler was also a bibliophile and a strong supporter of libraries and library associations. While at McGill he served on the Faculty Library Committee; in Philadelphia, he served on the Library Committee of the College of Physicians; in Baltimore, he was a member of the Library
Committee of the Medical and Chirurgical Faculty of the State of Maryland; and at Oxford, he was a Curator of the Bodleian Library. He was one of the founders and was the second President of the Association of Medical Librarians (which became the Medical Library Association) (6). He later founded and became the first and only President of the (short-lived) Association of Medical Libraries of Great Britain and Ireland $(7,8)$. He donated books to libraries throughout his career - sometimes with such enthusiasm that he tried to donate the same book several times to the same library. For example, he attempted to donate a second original Vesalius' monumental 1543 work on anatomy De Humani Corpus Fabrica to the New York Academy of Medicine!

As expected of a bibliophile, Osler was also a book collector and, by the time he died, had assembled a personal collection of about 8,000 items. His aim was to create a library containing a record of the history of medicine and he attempted to include both primary works and secondary "commentaries". His collection included about 140 incunabula (books published before 1501); many rare primary works, such as first editions of Vesalius' de Fabrica and Harvey's de Mortu Cordis; and many commentaries and secondary works on the history of medicine. His collection also contained books showing the relationship between medicine as art, and medicine as science. In addition, the collection contained a sizable section of books on medicine in literature.

In about 1912, Osler decided to leave his library to McGill University. When he died in 1919, the whole collection, with the exception of a few items donated to other libraries, was bequeathed to McGill's Faculty of Medicine. Osler made this generous gift for several reasons: In his introduction to the catalogue, the Bibliotheca Osleriana, he wrote "as a young, untried man, McGill College offered me an opportunity to think and to work; but what is more, the members of the Medical Faculty adopted me, bore with vagaries and aggressiveness, and often gave practical expressions of sympathy with schemes which were costly and of doubtful utility" (9). Osler was also moved by pride in his Alma Mater and by "loyalty to the country of one's birth and breeding." Due to the need for a suitable space to be prepared at McGill and, more importantly, because of the need to complete the catalogue, it took ten years for the collection to reach Montreal. Osler had started to compile the catalogue before his death and it was completed in Oxford by four of 


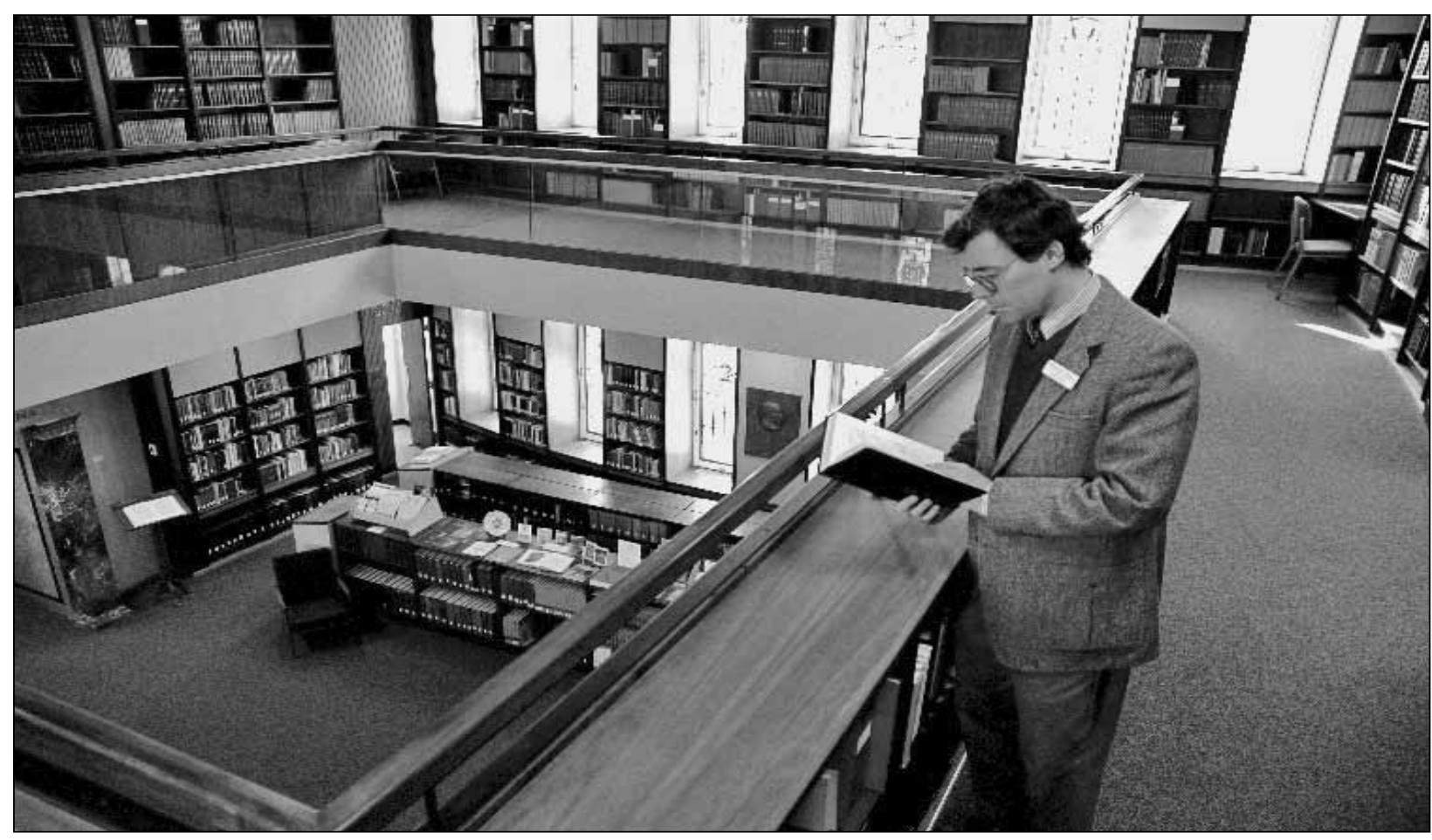

Figure 2: Mezzanine, The Osler Library of the History of Medicine

his friends (under the watchful eye of Lady Osler). This effort was led (very slowly!) by his cousin's son William Willoughby Francis. The catalogue has been described as "... probably the most complete well-annotated bibliography in the history of medicine. It reveals Osler's character better than any of his writings and stands as a monument to him," (10). The Bibliotheca was originally published in 1929 and was reprinted, with corrections and an additional prologue in 1969. It remains in-print and is available from the Library and online.

The original Osler Library was designed in the 1920s by the famous Montreal architect Percy Nobbs and built before the books arrived from Osler's home in Oxford. The original library was located in the Strathcona Medical Building, adjacent to the Medical Library. The central focus of the library (then comprising only one large room, now called the Osler Room in its current location) was a bronze plaque of Osler, under which the ashes of both Sir William and Lady Osler (who died in 1928) were placed. The library opened, amid a great deal of pomp and ceremony, in 1929 (11). In his biography of Osler the Canadian historian Michael Bliss has described the Osler Room as "a shrine, architecturally a cross between a church and a mausoleum," (3).
William Willoughby Francis, a Canadian who had a medical degree from Johns Hopkins, had been appointed Osler Librarian by McGill University in 1921 and, tellingly, often referred to himself as "Osler's Librarian". Until his death in 1959 he maintained, in the rather biting words of one commentator, "the Mecca for Osler devotees, a memorial and museum designed to perpetuate the inspiration which Osler had instilled in his followers ...he kept Osler in the forefront and never allowed the Library to become anything more than Osler's Library," (12).

Osler had instructed that the library should have a Board of Curators, whose existence and composition was clearly influenced by the Curators of the Bodleian Library (13). The library did grow during the years of Francis' reign, but the meetings of the Curators were not easy, as Francis strongly resisted any attempt to expand "Osler's Library,"(14). However, by 1963, despite this resistance, the library had doubled in size to about 17,500 volumes.

Much has changed since Francis died. First, in 1964-65, the library was moved into the new Mclntyre Medical Sciences Building. This was not a simple move, as it involved moving not only the library collections but also the original 
Nobbs-designed Osler Room. This beautiful room was dismantled and rebuilt inside the panhandleshaped wing adjacent to the Medical Library. This wing provided some expansion space for both the collection and the staff and allowed the creation of the Wellcome Camera (See Figure 2).

Shortly afterwards all of the pre-1851 material in the adjacent Medical Library was transferred to the Osler. The McGill Medical Library (later named the Health Sciences Library and now, the Life Sciences Library), was founded in August 1823 and is Canada's oldest medical library. The approximately 4,000 volumes transferred from it to the Osler Library added further treasures to Osler's collection (and the sale of the inevitable duplicates brought in some additional funds). The Osler Library also benefitted from the transfer of several thousand medical books published between 1850 and 1913 from remote storage. The rest of the material in remote storage, namely nineteenth and twentieth century journals and books from 1914 to 1974 , were moved to open storage and are easily accessible. The extensive collection of nineteenth and twentieth-century material held at McGill in the Osler and elsewhere means that this most fecund period of medical advancement is well represented.

Francis had taught "history of medicine" at McGill and by the mid-1960s a more formal Department of the History of Medicine was established, This Department was also allocated space adjacent to the two libraries. In the mid1970s the Osler Library and the Department were given some adjacent space and in April 1978 the Francis Wing opened. All this provided a larger rare-book area, more offices for both the library and the Department, and some additional space for the circulating collection. However, by the late 1990s this space had been more than filled and the Department had expanded (and changed its name to the Department of Social Studies of Medicine to better reflect its interests in the history, anthropology and sociology of medicine). As the close physical and intellectual links between the Osler Library and the Health Sciences Library were mutually beneficial, and it was virtually impossible to move the Nobbs-designed Osler Room again, and the decision was made to relocate the History of Medicine Department. Most of the space left vacant by this move was then allocated to the Osler Library and the whole area was renovated to provide additional shelving, better security and environmental conditions, enhanced study areas and offices. The John P. McGovern Foundation largely underwrote the cost of this major project and the newly expanded library re-opened in November 2002.

Osler's original donation had been composed of both "rare books" and current secondary works and the Bibliotheca includes several items published after Osler's death. The library now adds about 1,000 recently-published books each year (most of which are available for loan) and also acquires out-of-print or "rare books" by both donation and purchase. The library has two major collections of medical theses, about 1,100 from the University of Edinburgh (1790-1821) and about 30,000 French theses from the Université de Paris (1796-1920) (15).

The Osler Library collection now totals about 100,000 printed volumes, including the theses, and the library subscribes to approximately 200 current serials in all aspects of the history of the health sciences. As the Osler Library is a component of the McGill University Library, it benefits from McGill University's licensing of e-book and journal collections such as Early English Books Online and Early Canadiana Online and, of course, can draw on printed material in related subject areas held in other McGill libraries. The Osler is unusual for a "history of medicine collection" as it contains both rare and circulating material and is now one of the largest history of medicine libraries in the world -- certainly the largest in Canada. In addition to books and archives, the library has a small, and static, collection of medical artifacts, including one of Osler's microscopes and one of Norman Bethune's pneumothorax machines.

Information on all of the library's printed and manuscript collections is included in the McGill Library Catalogue (http://catalogue.mcgill.ca/F). As a service to students and researchers, the library has tried to make some of its reference resources available through special databases that are listed in the McGill Library Catalogue and in some cases linked to on the Osler Library's website. These include databases of the library's "reprint" and "medical almanac" collections and the Canadian Health Obituary Index (which lists nineteenth and twentieth century obituaries of health professionals). The library has quite substantial archival collections and collection-level records for most of these 150 fonds are also available in a database linked to in the Catalogue and on the Osler website (http:// osler.library.mcgill.ca/archives). Most of these fonds are connected to Osler, the Osler family, McGill and Montreal medicine. Notable works include: 
the papers of Wilder Penfield (the founder of the Montreal Neurological Institute) and the papers of Maude Abbott (who established what was to become the International Academy of Pathology).

The Osler Library tries to collect scholarly material on the history of the health sciences from all over the world. It has volumes in many languages, though it focuses on western European ones. The Library makes special efforts to buy any material published on the history of Canadian health sciences, including institutional histories and biographies and autobiographies of health care practitioners. (In the case of Canadian material, the Library tries to add even "non-academic" primary and secondary material.)

Medical students and practitioners may be interested in the library's collection of "pathographies" which are narratives written by patients chronicling their experiences. These are seen as a good vehicle for developing an understanding of and empathy for their patients. There are also fictional works written by doctors or which have a medical setting, such as the recent Giller Prize-winning collection of stories by Toronto emergency room doctor Vincent Lam entitled Bloodletting and Miraculous Cures,

The Osler Library currently has a staff of four: two librarians and two library assistants. It relies on the Life Sciences Library for circulation services and the McGill Library Collection Services for acquisitions and cataloguing. The Osler staff are also involved in teaching courses about the library's resources. The library has recently developed a number of student guides to the literature, available on the Library's website. The Osler Library has an active Friends group and publishes a regular Newsletter (available online at http://www.mcgill. ca/library/library-using/branches/osler-library/ oslernews) as well as a series of books on medical history (Osler Library Studies in the History of Medicine). Information on these books is available on the Library website at http://www.mcgill.ca/ library/library-using/branches/osler-library/shop . To assist scholars who need to use the library's resources the Library sponsors an annual Research Travel Grant to allow scholars to travel to Montreal http://www.mcgill.ca/library/library-using/branches/ osler-library/grant/.

The Osler Library has also begun to digitize its special collections. Currently an online collection of photographs of Sir William, his friends and family, entitled The William Osler Photo Collection, is available (http://digital.library.mcgill.ca/osler). The library also recently launched The Marjorie Howard Futcher Photo Collection, which consists of two digitized photo albums of the daughter of former Dean of Medicine R. Palmer Howard This site shows the strong connections between the Montreal social and medical elites in the late nineteenth and early twentieth century (http://digital.library.mcgill.ca/ futcher).

Although the library is no longer only "Osler's Library", it has become "The Osler Library". It continues to fulfill the aim set out by William Osler almost a century ago: to provide everyone who is interested (Canadians in particular) with a worldclass collection illustrating the development of the health sciences.

\section{DISCLOSURE}

An earlier version of this article was originally published by the Journal of the Canadian Health Libraries Association/ Journal de l'Association des bibliothèques de la santé du Canada ("JCHLA/ JABSC").

\begin{abstract}
A library represents the mind of its collector, his fancies and foibles, his strength and weakness, his prejudices and preferences. Particularly is this the case if to the character of a collector he adds - or tries to add- the qualities of a student who wishes to know the books and the lives of the men who wrote them. The friendships of his life, the phases of his growth, the vagaries of his mind, all are represented.
\end{abstract}

\section{-William Osler (16)}

\section{REFERENCES}

1. Osler W. The library school in the college. Libr Assoc Rec. 1917;17:288.

2. Cushing $\mathrm{H}$. The Life of Sir William Osler. Oxford: Clarendon Press; 1925.

3. Bliss M. William Osler: a life in medicine. Toronto: University of Toronto Press; 1999.

4. Golden RL. A history of William Osler's The principles and practice of medicine. Osler Library studies in the history of medicine, No. 8. Montreal: Osler Library; 2004.

5. Golden RL. The works of Egerton Yorrick Davis, MD: Sir William Osler's alter ego. Osler Library studies in the history of medicine, No. 3. Montreal: Osler Library; 1999. 
6. Connor JJ. Guardians of medical knowledge: the genesis of the Medical Library Association. Lanham, Md.: Medical Library Association/Scarecrow Press; 2000.

7. Crawford DS. The Medical Library Association of Great Britain and Ireland. Health Info Libr J. 2004;21:266-68.

8. Ferguson $\mathrm{V}$. The professionalization of health librarianship in the UK between 1909 and 1978. Health Info Libr J. 2005;22(Suppl 1): 8-19.

9. Bibliotheca Osleriana: a catalogue of books illustrating the history of medicine and science. Oxford: Clarendon Press; 1929. Reprinted with addenda and some additional material; Montreal: McGill - Queens University Press; 1969.

10. Morton LT. A medical bibliography (Garrison and Morton): an annotated checklist of texts illustrating the history of medicine. Philadelphia: Lippincott; 1970.

11. Miller PJ. Preserving medical history: recent renovations to the Osler Library. In: Conner E, editor. Planning, renovating, expanding, and constructing library facilities in hospitals, academic medical centers, and health organizations. Binghamton, N.Y.: Haworth; 2005. p. 25-42.
12. Summary of impressions arising from a close examination of the curators' minute book. Minutes of the Board of Curators, Osler Library of the History of Medicine, 1967.

13. Grant N. Sir William and the Osler Library's Board of Curators. Osler Libr Newsl. 1969;2:1-5.

14. Wallis F. I am Osler's nephew and librarian: W.W. Francis at the helm of the Osler Library. Osler Libr Newsl. 1995;80:15 .

15. Crawford DS. Theses in the Osler Library including that of Pierre de Sales Laterriére. Osler Libr Newsl. 2009;111:111.

16. Osler W. The collecting of a library. In Bibliotheca Osleriana: a catalogue of books illustrating the history of medicine and science. Oxford: Clarendon Press; 1929. Reprinted with addenda and some additional material; Montreal: McGill Queens University Press; 1969. 